\title{
GLACIAL STAGE ICE-CORE RECORDS FROM THE SUBTROPICAL DUNDE ICE CAP, CHINA
}

\author{
by \\ L.G. Thompson, E. Mosley-Thompson, M.E. Davis, J.F. Bolzan, J. Dai, L. Klein, \\ (Byrd Polar Research Center, Ohio State University, Columbus, OH 43210, U.S.A.)
}

N. Gundestrup

(Isotope Laboratory, Geophysical Institute, University of Copenhagen, Denmark)

T. Yao, X. Wu and Z. Xie

(Lanzhou Institute of Glaciology and Geocryology, Academia Sinica, Lanzhou, China)

\begin{abstract}
The first ice-core record of both the Holocene and Wisconsin/Würm Late Glacial Stage (LGS) from the subtropics has been extracted from three ice cores to bedrock from the Dunde ice cap on the north-central Qinghai-Tibetan Plateau. Ice thicknesses at the ice-cap summit average $138 \mathrm{~m}$, the bedrock surface is relatively flat, surface and basal temperatures are -7.3 and $-4.7^{\circ} \mathrm{C}$, respectively and the ice cap exhibits radial flow away from the summit dome. These records reveal a major change in the climate of the plateau $\sim 10000$ years ago and suggest that LGS conditions were colder, wetter and dustier than Holocene conditions. This is inferred from the more negative $\delta^{18} \mathrm{O}$ ratios, increased dust content, decreased soluble aerosol concentrations, and reduced ice-crystal sizes, which characterize the LGS part of the cores. Total $B$ radioactivity from shallow ice cores indicates that over the last 24 years the average accumulation rate has been $\sim 400 \mathrm{~mm} \mathrm{a}^{-1}$ at the summit. The ice cores have been dated using a combination of annual layers in the insoluble dust and $\delta^{18} \mathrm{O}$ in the upper sections of core, visible dust layers which are annual, and ice-flow modeling. The oxygenisotope record which serves as a temperature proxy indicates that the last 60 years have been the warmest in the entire record.
\end{abstract}

\section{INTRODUCTION}

Reliable meteorological and climatological information for climate reconstruction is scarce or absent for many parts of the world, especially on much of the Qinghai-Tibetan Plateau and surrounding mountains (Domrös and Peng, 1988). The high-altitude ice caps on this plateau offer the potential for recovery of a well-dated archive of atmospheric history from the subtropics on glacial timescales. Although cores have been retrieved successfully from the polar regions over the last three decades the recovery of ice cores from high-altitude sites is a rather recent development (Wagenbach, 1989). The recovery of ice-core climatic records from the Tibetan Qinghai Plateau will be essential to understand the global climate system, particularly in view of the impact of this region on northern hemisphere meteorology and climate.

The Dunde ice cap $\left(38^{\circ} 06^{\prime} \mathrm{N}, 96^{\circ} 24^{\prime} \mathrm{E}\right)$ is located in a desert environment between the highest Chinese desert, the Qaidam Basin, to the south, and the Gobi Desert to the north (Fig. la). A combination of glaciological and meteorological factors: glacier thickness $140 \mathrm{~m}$, flat bedrock topography, low net accumulation $(0.4 \mathrm{~m}$ of water equivalent per year) and low mean annual temperature of $-7.3^{\circ} \mathrm{C}$, makes the ice cap well suited to the recovery of long-term, high temporal-resolution ice-core records. Co-operative glaciological and climatological research programs were conducted on the Dunde ice cap in 1984, 1986, and 1987 by the Byrd Polar Research Center (BPRC) and the Lanzhou Institute of Glaciology and Geocryology (LIGG). In 1987, three ice cores (Figs $\mathrm{lb}$ and c) were recovered to bedrock from the ice-cap summit $(5325 \mathrm{~m}$ a.s.l.). Core D-1 (139.8 $\mathrm{m}$ long) was divided along the entire length in the field and shared equally between LIGG and BPRC. Core $\mathrm{D}-2$ ( $136.6 \mathrm{~m}$ long) was returned frozen to the LIGG and core D-3 (138.4 m long) was returned to BPRC (Thompson and others, 1988a). The upper $56 \mathrm{~m}$ of core D-3 were melted and bottled while the lower $83 \mathrm{~m}$ were returned frozen to BPRC.

\section{ICE-CORE ANALYSES}

The visible stratigraphy of each core was photographically recorded immediately after drilling. Core D-1 was then cut into 3585 samples which were melted in closed containers by passive solar heating within a laboratory tent. The samples were then poured into polyethylene bottles, sealed in wax, and shipped to BPRC. Samples were divided so that microparticle concentrations (MPC), oxygen isotopic ratios $\left(\delta^{18} \mathrm{O}\right)$ and liquid electrical conductivity (EC) could be measured on the same sample. The concentrations of three inorganic anions and $\mathrm{pH}$ were measured for the entire length of D-3 while crystal sizes were measured for selected sections.

Core D- 1 was analyzed along the entire length for MPC, $\delta^{18} \mathrm{O}$ and EC. $\delta^{18} \mathrm{O}$ was measured at the University of Copenhagen and all other measurements were made at BPRC under Class 100 Clean Room conditions. The concentrations of particles with diameters $\geqslant 2 \mu \mathrm{m}$ per milliliter sample (MPC) were measured using a model TA-II Coulter Counter (Thompson, 1977), fitted with a $100 \mu \mathrm{m}$ aperture tube. The very high concentratlons of dust necessitated diluting most of the samples 36 times, and up to 7000 times in extreme cases, to avoid problems with coincident passage through the aperture tube. Only samples for dust measurements were diluted. EC of liquid samples was measured with a Beckman model RC-16C conductivity bridge; $\mathrm{pH}$ was measured with a Beckman model $\Phi 40 \mathrm{pH}$ meter.

The concentrations of seven major soluble ions, chloride $\left(\mathrm{Cl}^{-}\right)$, sulfate $\left(\mathrm{SO}_{4}^{2-}\right)$, nitrate $\left(\mathrm{NO}_{3}^{-}\right)$, sodium $\left(\mathrm{Na}^{+}\right)$, potassium $\left(\mathrm{K}^{+}\right)$, magnesium $\left(\mathrm{Mg}^{2+}\right)$ and calcium $\left(\mathrm{Ca}^{2+}\right)$, were determined with a Dionex Model 2010i chromatograph, equipped with AS4A (for anions) and FAST SEP CATION I and II (for cations) columns. All ion chromatographic 


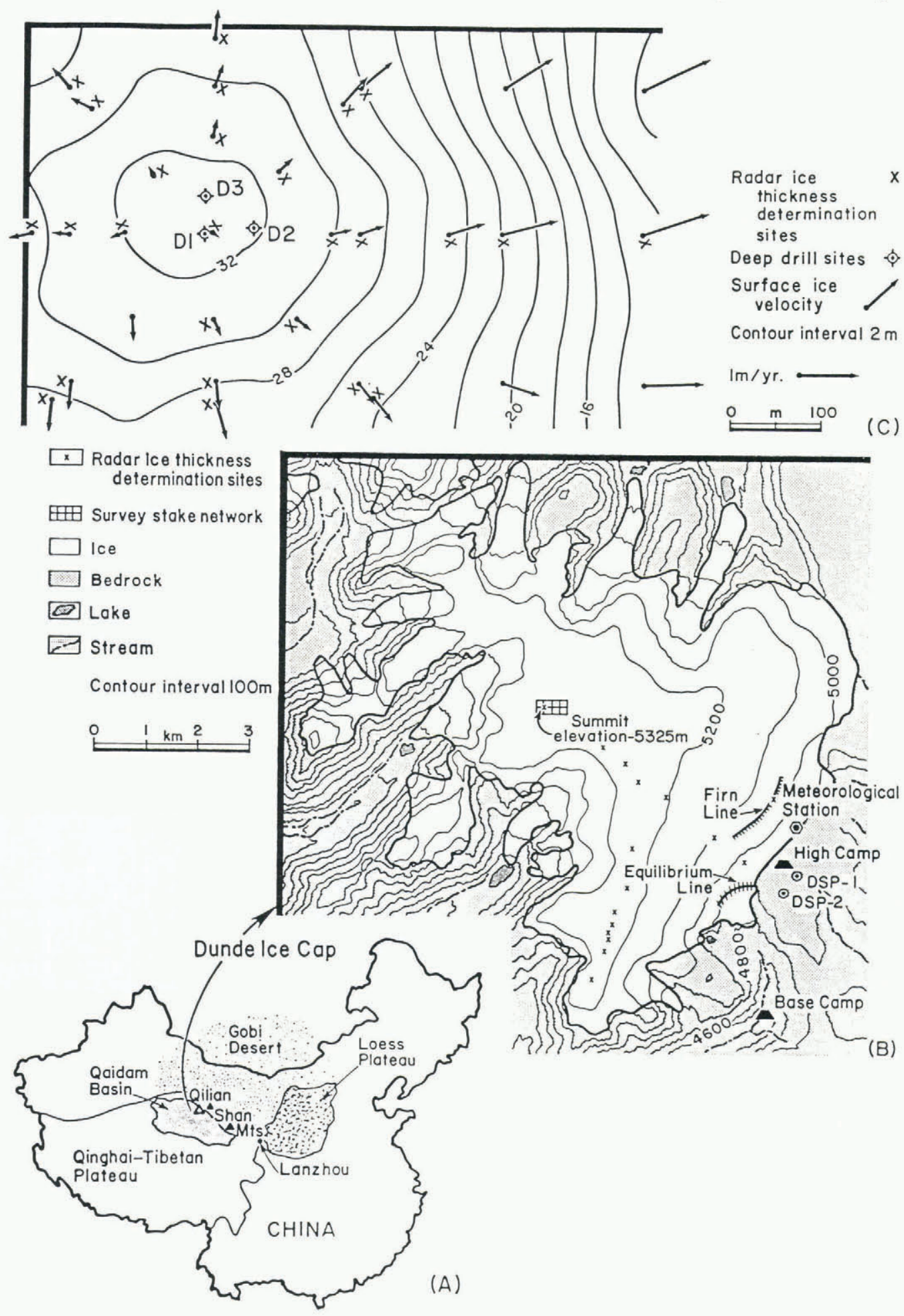

Fig. 1(A). Location of the Dunde ice cap, Qaidam Basin, and Loess Plateau; (B) topography of the ice cap, position of the survey network, firn and equilibrium lines, and sites where ice thickness was determined; (C) location of drill sites (D1, D2, and D3), detailed surface topography, inferred flow lines and ice velocities.

samples were passed through $0.2 \mu \mathrm{m}$ mesh filters prior to analysis. The cations were determined in selected sections, while the anions were measured for the entire lẹngth of core D-3 (c. 1200 samples of varying length from 40 to $5 \mathrm{~cm}$ from the top to the bottom of the core). Some minor ions, namely ammonium, acetate, formate, oxalate and phosphate, were also detected in ion chromatographic measurements.

Samples of $200-250 \mathrm{~g}$ were cut from both the D-1 and
D-3 cores and pumped through ion-exchange filters to measure total $\beta$ radioactivity in a Tennelec LB 1000 Series $\alpha / \beta$ Counting System. Total $\beta$ radioactivity is routinely used to identify time-stratigraphic horizons associated with known atmospheric thermonuclear tests (Crozaz and others, 1966). When isolated in an ice core, these horizons (Picciotto and Wilgain, 1963) allow verification and calibration of seasonally varying parameters which are used to date the core. 
(A)

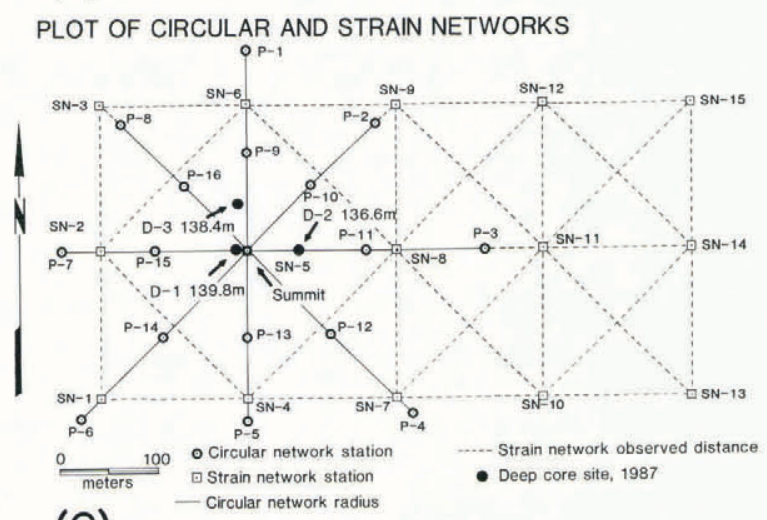

(C)

BEDROCK TOPOGRAPHY

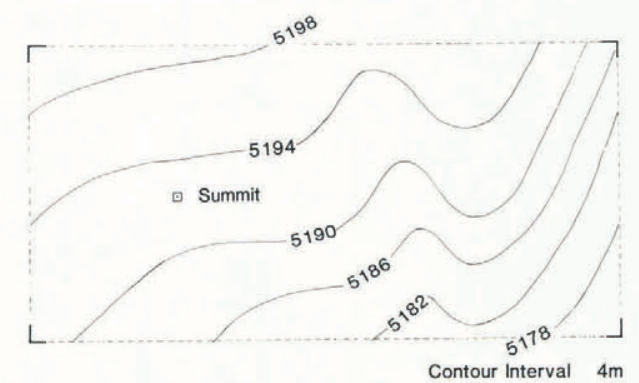

(B)

SURFACE TOPOGRAPHY

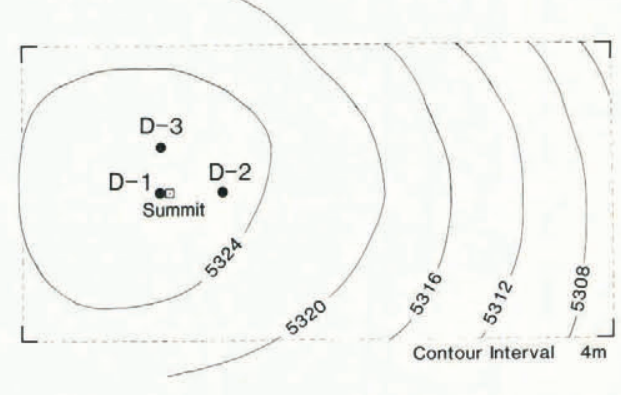

(D)

\section{ICE THICKNESS}

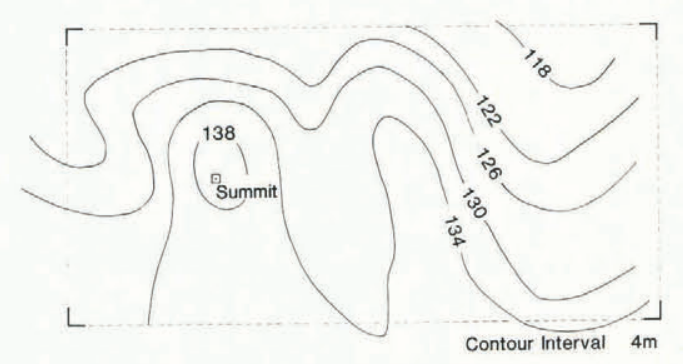

(E)

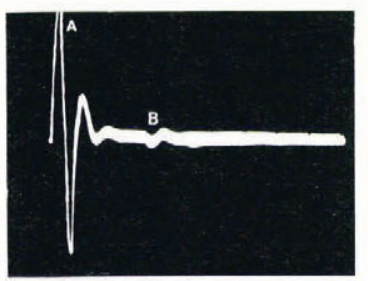

$130.2 \mathrm{~m}$

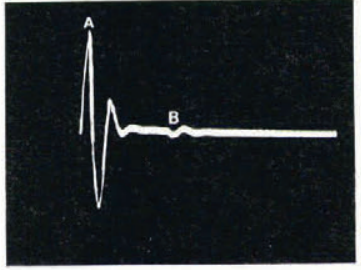

$131.8 \mathrm{~m}$

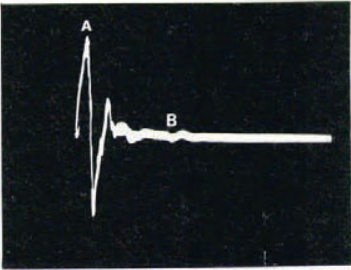

$133.4 \mathrm{~m}$

Fig. 2. Summit area of the Dunde ice cap showing (A) circular and strain network, (B) a contour map of surface topography, (C) a contour map of bedrock topography, (D) an isopach map of the ice thickness, and (E) typical echograms obtained from the summit area of the Dunde ice cap showing the complete wave train including the surface wave (A) and the reflected wave (B).

\section{GEOPHYSICAL STUDIES}

A short-pulse ice-radar sounder was used on the Dunde ice cap to determine ice thicknesses. The system used has been described elsewhere (Jezek and Thompson, 1982; Thompson, 1989). Examples of radar data collected from the summit of the Dunde ice cap are illustrated in Figure 2. The complete wave train includes the surface wave (A) which travels along the upper surface of the air-snow interface, arrivals scattered from features within the ice, and a strong echo (B) which is interpreted as the reflection of the ice-rock boundary. Very few of the waves interpreted as reflections from the ice-rock interface appear to be distorted, and there are no strong arrivals later than the bedrock reflections, suggesting that the bedrock surface is relatively smooth. The ice-cap summit topography was extensively surveyed and radar soundings were made at 42 sites (Thompson, 1989). At the drill sites for cores D-1 and D-3 the measured depths between the surface and the bedrock were 139.6 and $138.4 \mathrm{~m}$, respectively, while the average short-pulse ice-radar thicknesses were 142.4 and $140.3 \mathrm{~m}$, respectively, providing a radar accuracy within $2 \%$.
The radar data and the surface survey data were used to produce a contour map of the surface topography, a contour map of bedrock topography, and an isopach map of the ice thickness (Figs. 2b, c, d). The three deep core sites (Fig. 2b) are located near the summit dome of the ice cap and the bedrock surface is gently sloping to the southeast (Fig. 2c).

Temperature profiles were measured at 5 and $10 \mathrm{~m}$ intervals in each of the three bore holes using a $150 \mathrm{~m}$ thermistor cable designed with two thermistors at each point to allow cross-checks of temperature measurements at each depth. The resulting core 1 bore-hole temperature profile is presented in Figure 3a. The $10 \mathrm{~m}$ surface and basal borehole temperatures were -7.3 and $-4.7^{\circ} \mathrm{C}$ respectively, indicating that the Dunde ice cap is "polar."

\section{LATE GLACIAL STAGE ICE}

Late in the 1986 field season ice merging along the margin of the Dunde ice cap contained an abrupt contact between overlying clean ice and underlying dirty ice. MPC and $\delta^{18} \mathrm{O}$ analyses of two shallow cores drilled through this 


\section{TEMPERATURE ${ }^{\circ} \mathrm{C}$}

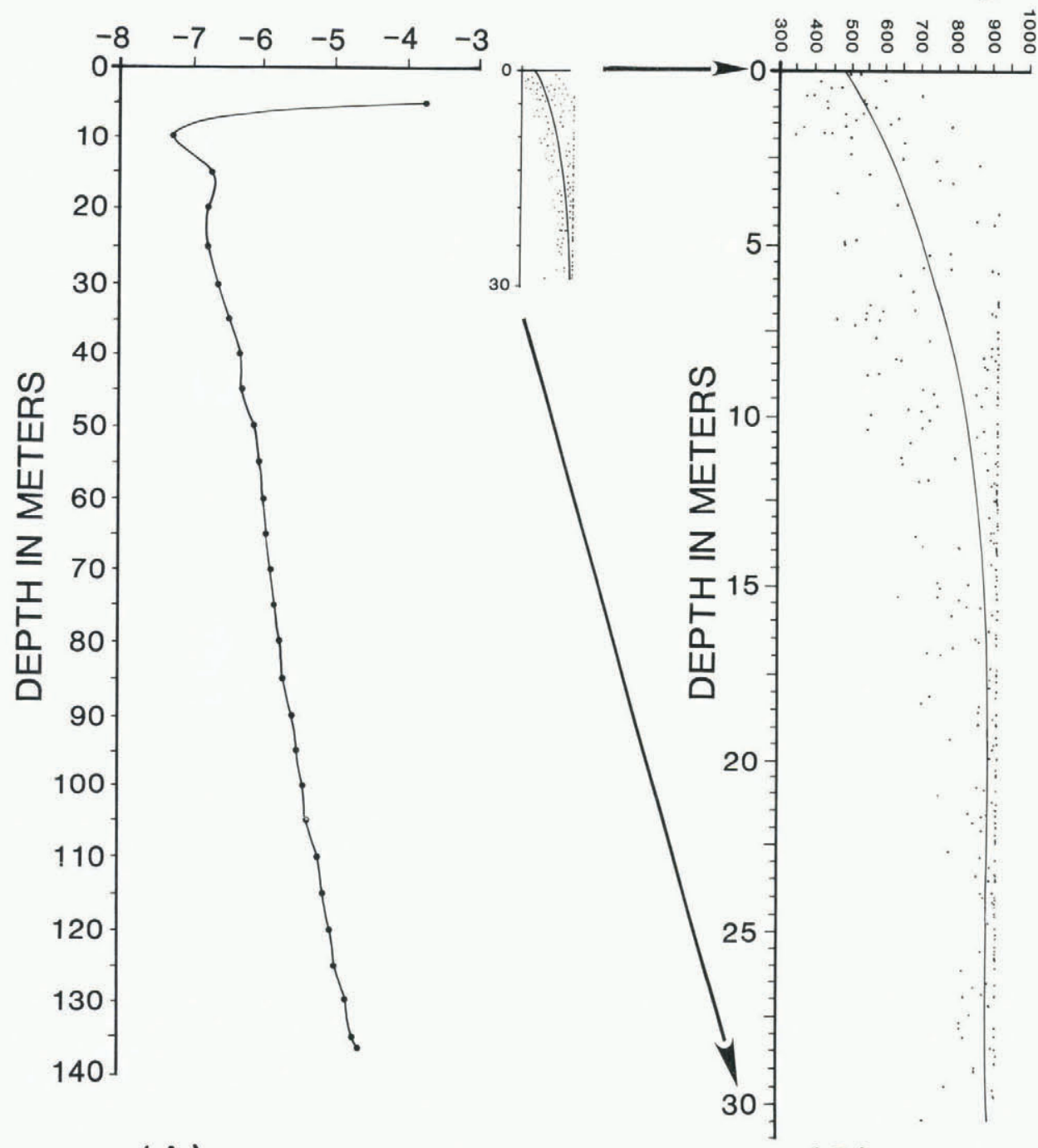

( $A$ )

( B)

Fig. 3(A). Temperature profiles measured at $5 \mathrm{~m}$ intervals in the core 1 bore hole on the summit of the Dunde ice cap in 1987. The temperature profile indicates that the ice cap is "polar" throughout with a bottom temperature of $-4.7^{\circ} \mathrm{C}$. (B). $30 \mathrm{~m}$ density profile for Dunde ice cap. Measured values are indicated by dots, while the smooth curve is a third-order best fit to the measured values. The depth $(X)$-density $(\rho)$ relationship is expressed as $\rho=A+B X+C X^{2}+D X^{3}$ where $A=473.558$, $B=55.233, C=-2.418$, and $D=0.0346$. For this fit $r^{2}=0.557$ which is statistically significant at the $99.9 \%$ confidence level.

transition indicated that the underlying ice is probably of Wisconsin/Würm Late Glacial Stage (LGS) age (Thompson and others, 1988a). The results from core D-1 drilled at the summit confirm that a strong temporal relationship exists between the large increase in dust below $129.2 \mathrm{~m}$ and $\delta^{18} \mathrm{O}$ depletion (Fig. 4) in the ice. The LGS ice contains major dust events where concentrations are 4-8 times average Holocene concentrations. Concurrently, mean $\delta^{18} \mathrm{O}$ decreases by $2 \%$. Just as observed in Greenland cores from Camp Century (Thompson, 1977) and Dye 3 (Hammer and others, 1985), the transition from high to low-dust concentrations is very abrupt (Fig. 4b) across the LGS/Holocene boundary. In Dunde ice cores this transition in the dust concentration is contained in a $30 \mathrm{~cm}$ section of ice representing approximately 40 years.

Figure $4 \mathrm{~b}$ illustrates MPC and $\delta^{18} \mathrm{O}$ in the lower $20 \mathrm{~m}$ of $\mathrm{D}-1$ and similarly $\mathrm{Cl}^{-}, \mathrm{NO}_{3}^{-}$and $\mathrm{SO}_{4}^{2-}$ in $\mathrm{D}-3$. The more negative $\delta^{18} \mathrm{O}$ ratios in the lower $10 \mathrm{~m}$ support the presence of LGS ice. However, unlike the rapid transition in MPC and anion concentrations, the ${ }^{18} \mathrm{O}$ enrichment in precipitation appears more gradual suggesting that Holocene conditions were attained over several centuries.
Chloride, nitrate and sulfate concentrations in core D-3 (Fig. 4) show large variations with depth, as well as infrequent, but extremely high concentrations. There are significantly positive correlations between concentrations of chloride, sulfate, sodium, calcium and magnesium. Throughout D-3 alkaline cations $\left(\mathrm{Ca}^{2+}, \mathrm{Mg}^{2+}\right.$ and $\left.\mathrm{Na}^{+}\right)$and $\mathrm{Cl}^{-}, \mathrm{SO}_{4}^{2-}$ and $\mathrm{HCO}_{3}^{-}$(estimated with $\mathrm{pH}$ ) constitute the majority of the dissolved species, indicating that the ice core is highly alkaline.

Throughout core D-3 the pH of melt-water samples remains essentially neutral (average $\mathrm{pH}=7.3$ ) with occasional values ranging from 5.7 to 9.2. For the few sections analyzed, cation and anion concentrations vary proportionally. For example, $\mathrm{Na}^{+}$and $\mathrm{Cl}^{-}$concentrations maintain a molarity ratio near unity for all sample sections for which both cations and anions were measured, indicating that these two ions share a common dominant source.

The most distinctive feature of the anion profiles is the marked concentration decrease in the lower $12 \mathrm{~m}$ of the core (Fig. 4), where average concentrations of $\mathrm{Cl}^{-}, \mathrm{NO}_{3}^{-}$and $\mathrm{SO}_{4}^{2-}$ are 30,50 , and $32 \%$ lower than their respective averages for the entire core. The evidence of co-variation 
(A) Total Particles $\geq 2.0 \mu \mathrm{m}$ per $\mathrm{ml}$ of sample $\left(\times 10^{5}\right)$
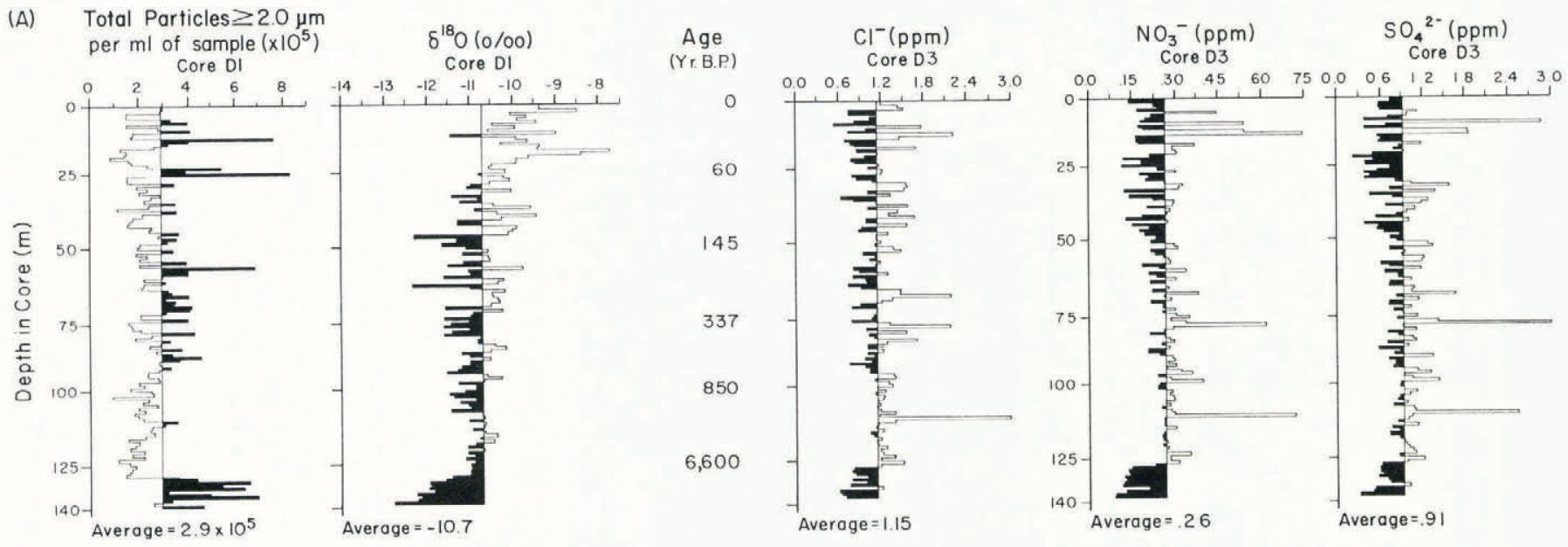

(B) Total Particles $\geq 2.0 \mu \mathrm{m}$
per $\mathrm{ml}$ of sample $\left(\times 10^{5}\right)$
Core DI
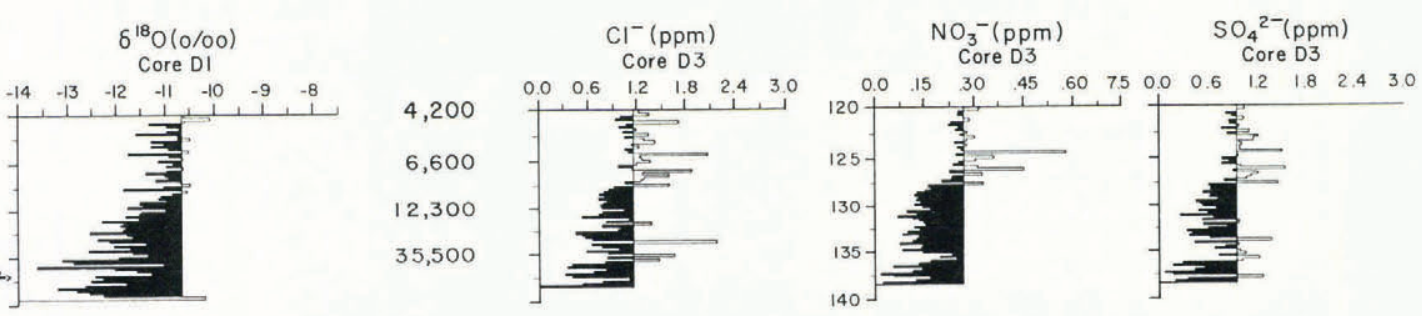

Fig. 4(A). Averages over $1 \mathrm{~m}$ depth intervals (roughly 25 samples per section in core D-1) for total particles (diameters $\geqslant 2.0 \mu \mathrm{m}$ ) per $\mathrm{ml}$ sample, $\delta^{18} \mathrm{O}, \mathrm{Cl}^{-}, \mathrm{NO}_{3}^{-}$, and $\mathrm{SO}_{4}^{2-}$. The time-scale is indicated at $25 \mathrm{~m}$ intervals. (B). Averages every $0.5 \mathrm{~m}$ interval (roughly 17 samples per section in core D-1) for the lower $20 \mathrm{~m}$ of the cores illustrate the rapid transition in the concentrations of dust and dissolved species and the more gradual $\delta^{18} \mathrm{O}$ transition.

between major anions and major cations suggests that cation concentrations are also lower in the bottom $12 \mathrm{~m}$ of the ice core. Indeed, one-meter averages of $\mathrm{Ca}^{2+}$ concentration decrease from $1.6 \mathrm{ppm}$ at mid-core $(64 \mathrm{~m})$ to $1.3 \mathrm{ppm}$ in LGS ice $(130 \mathrm{~m})$. A corresponding decrease in EC below $129 \mathrm{~m}$ was also observed in core D-1 (not shown). This decrease of the ionic concentrations in core $\mathrm{D}-3$ is temporally correlative with the increase in MPC below $129 \mathrm{~m}$ of core D-1, with a similarly abrupt transition.

No new ions were found below the LGS/Holocene transition. This suggests that the dominant sources of the soluble aerosol were essentially the same during both the LGS and Holocene. Later discussion demonstrates that the soluble aerosol is supplied by the deserts and surface mineral deposits surrounding the ice cap, and the higher concentrations in the Holocene are the result of the increased strength of the predominant local sources, due to the progressively drier climatic conditions. This is different from the polar areas, where LGS concentrations of soluble species $\left(\mathrm{Cl}^{-}, \mathrm{SO}_{4}^{2-}\right)$ are generally higher than those in the Holocene (Herron and Langway, 1985; Legrand and Delmas, 1988). The decrease of soluble aerosol from LGS to Holocene in the polar cores is attributed to a decrease of the meridional atmospheric circulation and increased precipitation, while reduced levels of insoluble dust are attributed to a decrease of both atmospheric circulation and continental aridity.

Ice-crystal sizes were measured for selected sections of D-3 in ice below $50 \mathrm{~m}$ (Fig. 5) to explore the possibility of a relationship with temperature (Petit and others, 1987) and dust (Koerner and Fisher, 1979) as reported in polar ice cores. Crystal growth rate increases with temperature (Duval and Lorius, 1980). Between 52 and $89 \mathrm{~m}$, a growth rate of $0.2 \mathrm{~mm}^{2} \mathrm{a}^{-1}$ was calculated, which, if applied to the entire core, should result in a crystal size of $300 \mathrm{~mm}^{2}$ at $128.5 \mathrm{~m}$. However, measured crystal size decreases substantially below $128 \mathrm{~m}$ where a minimum of $11.4 \mathrm{~mm}^{2}$ was measured, and changes sharply at the LGS/Holocene transition. Similarly, LGS ice in cores from Antarctica (Petit and others, 1987) and Greenland (Herron and Langway, 1985) is characterized by substantially smaller crystals and abrupt crystal size changes at the LGS/Holocene transition.
All these analyses lead us to conclude that the lower $10 \mathrm{~m}$ in the Dunde ice cap represent ice deposited during the last glacial stage. The high dust concentrations correlate closely with $\delta^{18} \mathrm{O}$ depletion (temperature proxy) as found in all polar cores extending below the LGS/Holocene transition. In fact, the association of high dust content and more negative $\delta^{18} \mathrm{O}$ has been used routinely for the last decade as the principal characteristic of LGS ice in polar ice cores, e.g. Camp Century and Dye 3, Greenland (Thompson and Mosley-Thompson, 1981a; Dansgaard and others, 1985); Ellesmere Island and Devon Island (Paterson and others, 1977; Koerner, 1977, Koerner and others, 1987); and, in Antarctica, Vostok (De Angelis and others, 1987); Byrd Station (Johnsen and others, 1972; Thompson and Mosley-Thompson, 1981a) and Dome C (Thompson and others, 1981b). In addition to the same $\delta^{18} \mathrm{O}$ and MPC characteristics which are found in glacial stage ice in polar cores, the decrease in ice-crystal size and the abrupt nature of concentration changes in both ions and insoluble dust at the glacial/interglacial transition further support the LGS age interpretation of the lower $10 \mathrm{~m}$ of each core.

\section{TIME-SCALE CONSTRUCTION}

Total $\beta$ radioactivity horizons from the upper parts of the $1987 \mathrm{D}-1$ and D-3 cores, as well as from the 1986 summit cores, provide time stratigraphic markers (Fig. 6) for verification of seasonal variability of MPC and $\delta^{18} \mathrm{O}$. As demonstrated in Figure 6, the 1963 radioactivity horizon is pronounced and provides an average accumulation rate of $\sim 400 \mathrm{~m}$ of $\mathrm{H}_{2} \mathrm{O}$, which is twice the 1980-86 rate of $\sim 200 \mathrm{~m}$ $\left(\mathrm{H}_{2} \mathrm{O}\right.$ equivalent) determined from snow-pit studies (Thompson and others, 1988b); however, it is similar to the measured values of $\sim 350 \mathrm{~m} \quad\left(\mathrm{H}_{2} \mathrm{O}\right.$ equivalent $)$ from 31 summit stakes for the 1986-87 accumulation year.

Figure 7 illustrates the annual MPC and $8^{18} \mathrm{O}$ cycles used to date the upper $70 \mathrm{~m}$ of $\mathrm{D}-1$. The diamonds mark the annual layers which thin with depth. Due to the low accumulation rate, coupled with rapid thinning with depth, layer separations below $70 \mathrm{~m}$ are too small to be resolved by analyzing seasonally varying parameters, as the average 


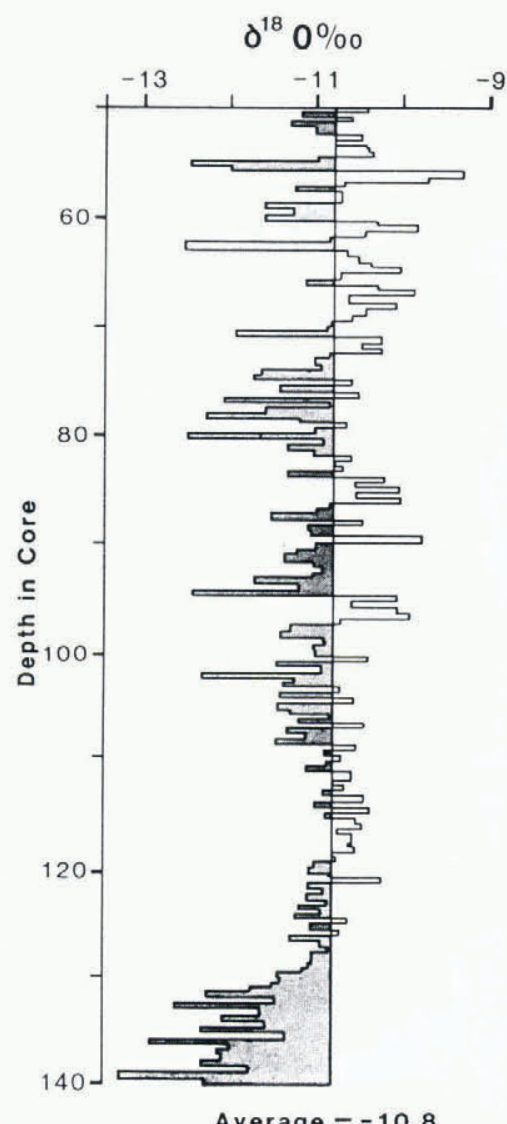

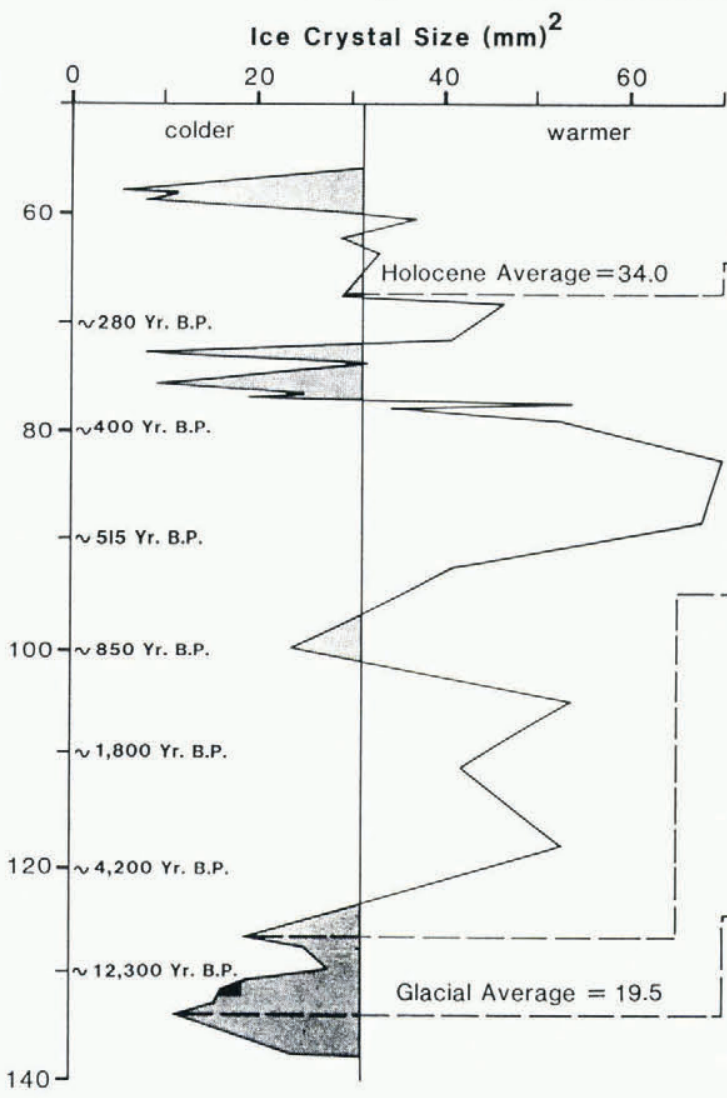

Total Average $=31.0$
Ice Crystals
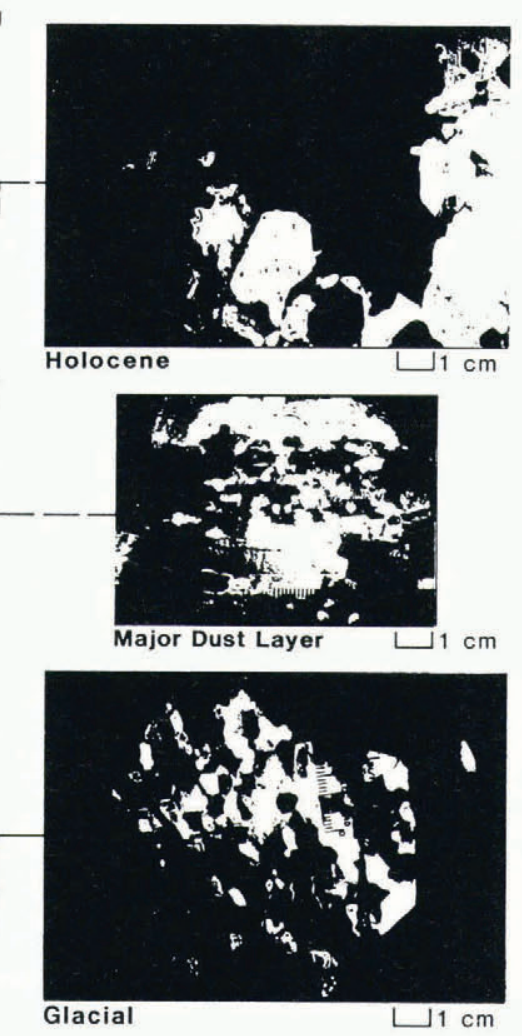

Fig. 5. Ice-crystal sizes measured for selected sections of core D-3, illustrated along with the $\delta^{18} \mathrm{O}$ record. Light micrographs illustrate ice crystals for sections of typical Holocene ice, ice containing a major dust layer and LGS ice near the ice-cap bottom.

sampling interval is $3.7 \mathrm{~cm}$. However, the enhanced dust deposition during the dry season produces an additional annual stratigraphic marker visible deeper in the ice. Between 70 and $117 \mathrm{~m}$, these visible dust layers were used for dating. The measured layer thicknesses from the visible dust layers as a function of depth are shown in Figure 8. Counting the annual $\delta^{18} \mathrm{O}$ and MPC peaks down to $70 \mathrm{~m}$, and the visible dust layers below $70 \mathrm{~m}$, provides an age of about 4550 year B.P. at $117 \mathrm{~m}$ depth.

If annual layers could be identified down to the stratigraphic transition at $129.2 \mathrm{~m}$ depth $(125.8 \mathrm{~m}$ ice equivalent), the corresponding age could be determined by simply counting the number of layers. Unfortunately, annual layers are too thin to be discerned below about $117 \mathrm{~m}$ depth. However, a lower boundary to the age can be estimated by assuming no additional layer thinning below the last measured value, which is about $0.0037 \mathrm{~m} \mathrm{a}^{-1}$. The resulting value is about 7000 year B.P.

The LGS/Holocene transition has been dated at 10750 year B.P. in the Camp Century ice core from northern Greenland (Hammer and others, 1986), and we seek to determine whether the thinning of measured annual layers is consistent with a similar age at the $129.2 \mathrm{~m}$ stratigraphic transition. A more refined estimate of the age of this horizon can be made by extrapolating the layer-thickness data. The measured variation of layer thickness with depth could be fitted with an $n$ th-order polynomial or an appropriate set of orthogonal functions. However, because the behavior of such least-squares, best-fit functions is not well constrained beyond the data region, the resulting extrapolation would not be very useful. Also, the scatter in the data is related to secular variations in the accumulation rate and, to a lesser degree, subsequent adjustments in the velocity field. Thus, extrapolating a least-squares fit to the data places unrealistic emphasis on the temporal variations that occur later in time than the interval of interest.

Instead, a more physical approach is taken and the nature of the flow to the bore hole is considered. Measurements of the detailed surface topography and surface velocities $\left(1.8 \mathrm{~m} \mathrm{a}^{-1}\right)$ around the bore hole indicate that the topographic summit is also the center of flow, or flow divide; and that the $\mathrm{D}-1$ bore hole is about $17 \mathrm{~m}$ southeast of the summit (Fig. 1c). Various studies (Raymond, 1983; Bolzan, 1985; Reeh, 1988) suggest that layers tend to thin more rapidly with depth near a flow divide than at distances many ice thicknesses away. Here the D-1 bore hole is much less than one ice thickness (about $136 \mathrm{~m}$ ice equivalent) from the flow divide and is well within the near-divide zone, which seems to be on the order of several ice thicknesses wide. Based on the analysis of a deep temperature profile in East Antarctica (Bolzan, 1985), a simple analytical representation for the annual layer thickness as a function of depth in the near-divide zone was found to be:

$$
L(z)=b(1-z / H)^{p+1}
$$

where $H$ is the ice thickness, $b$ is the accumulation rate in $\mathrm{m} \mathrm{a}^{-1}$, and $z$ is the ice-equivalent depth. To compute the time interval corresponding to a given depth interval, the inverse of the annual layer thickness (i.e. the number of years per meter) is integrated over the depth interval.

The accumulation rate $(b)$ is approximately the average value over the interval in question. Here only the average value over the past 25 years is known, and is assumed to be an appropriate value for the Early Holocene. The exponent $p$ is a priori unknown and is determined to be 1.612 by requiring the age to be 4550 years at $117 \mathrm{~m}$ depth, as given by the annual layer thickness data. With these values for $b$ and $p$, we find the age of the stratigraphic transition at $129.2 \mathrm{~m}$ depth (125.8 m ice equivalent) to be about 11950 year B.P.; within $10 \%$ of the assumed age (the calculated layer thicknesses as a function of depth are also shown in Figure 7). This result also supports the identification of the LGS/Holocene horizon on the basis of the ice-core stratigraphy.

We emphasize that this calculation provides only a rough estimate of the age deep in the core. We have ignored factors such as temporal variations in accumulation rate, ice-sheet shape, and the position of the flow divide, as the subsequent ice-sheet response to these changes is poorly understood; and rarely is sufficient information available to specify these secular changes. Nevertheless, it is 


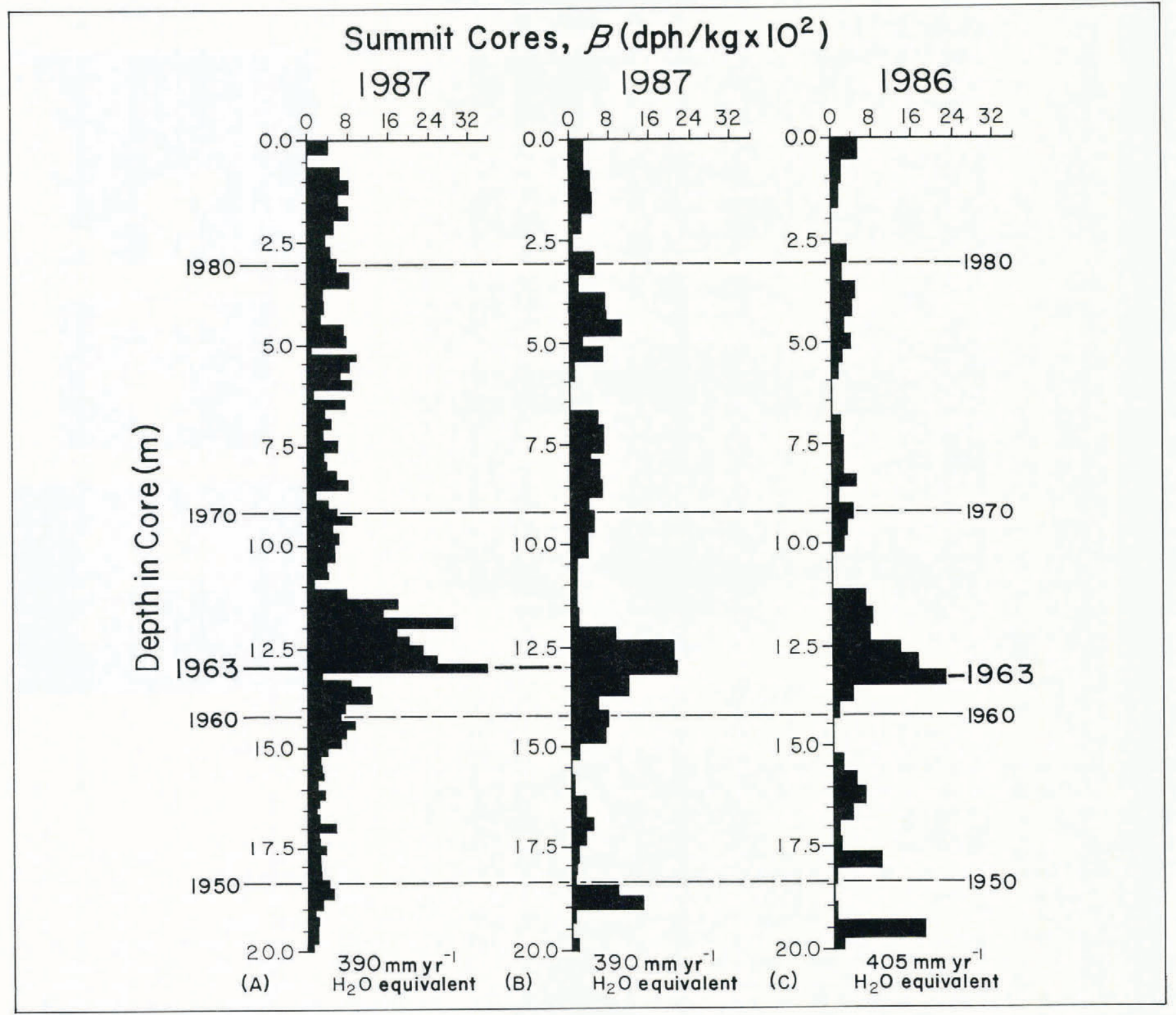

Fig. 6. B radioactivity results from three cores (two drilled in 1987 and one in 1986) at the summit provide an accurate determination of the present accumulation rate. From 1963 to 1987, the average annual accumulation is $390 \mathrm{~mm}$ of water equivalent and from 1963 to 1986 it is $405 \mathrm{~mm}$ water equivalent. Decadal time lines were determined by counting annual MPC and $\delta^{18} \mathrm{O}$ layers (Fig. 7).

(A)
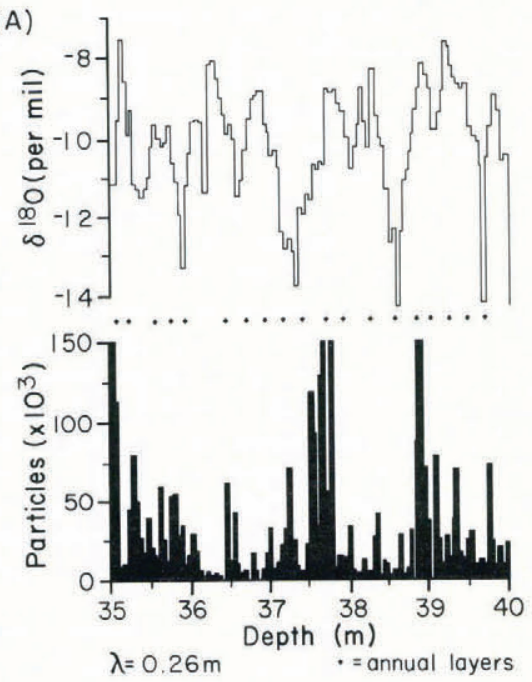

(B)
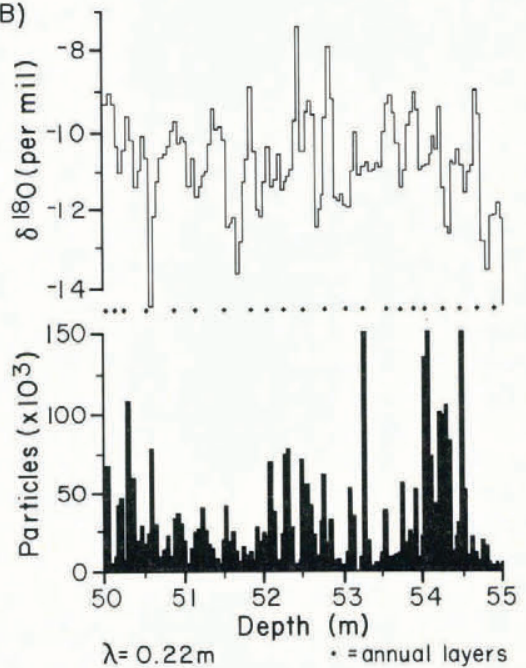

(c)
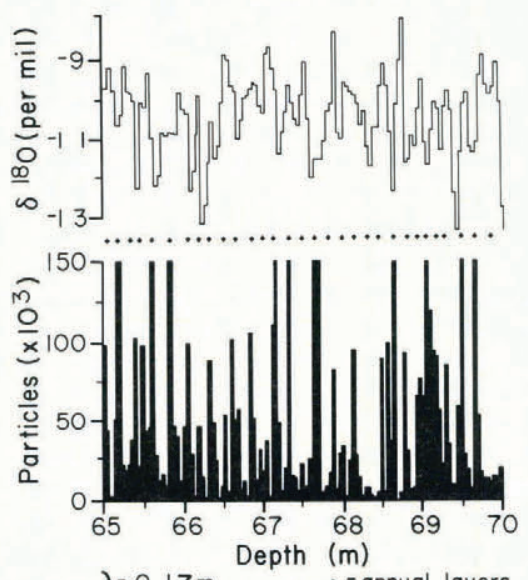

Fig. 7. Three representative $5 \mathrm{~m}$ ice-core sections illustrate the annual variations in total particles (diameter $\geqslant 2.0 \mu \mathrm{m}$ ) per $\mathrm{ml}$ of sample and $\delta^{18} \mathrm{O}$ which were used to date the upper $70 \mathrm{~m}$ of core $\mathrm{D}-1$. The diamonds indicate the annual layers. The average thickness $(\lambda)$ of the annual layers is shown; annual layer thinning is evident (see Fig. 6). 


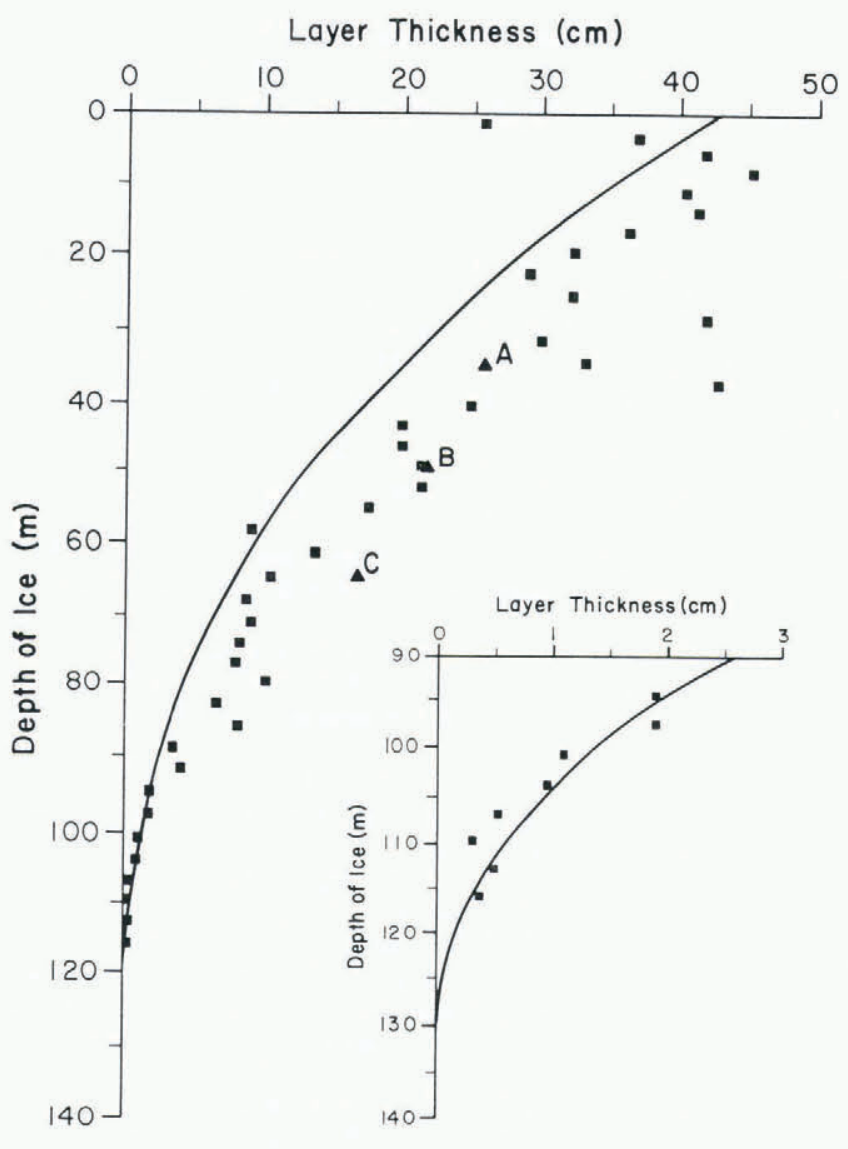

Fig. 8. The curve represents the calculated annual layer thicknesses (in $\mathrm{cm}$ of ice) as a function of depth in core $\mathrm{D}-1$. The squares illustrate the annual layer thicknesses based upon the visible dust layers. Data points A, B and $C$ were calculated from the annual MPC and oxygenisotope layers for sections illustrated in Figure 7. The insert shows the thicknesses in detail from $90 \mathrm{~m}$ to the bottom of the core. The curve represents the calculated variation of layer thickness with depth for the analytical representation described in the text with the parameters $p=1.612$ and $b=0.428 \mathrm{~m} \mathrm{a}^{-1}$. interesting to use the above results to estimate the timescale deeper in the core. To do this we recalculate the time-scale by fixing the age at the LGS/Holocene transition to be at 10750 year B.P. The resulting ages are indicated in Figure $4(\mathrm{a}, \mathrm{b})$ and in Figure 9. These results yield a preliminary age well in excess of 100000 years.

Of particular significance for the age of the bottom few meters would be the occurrence of basal melting, which could remove many thousands of years of ice from the bottom if a very small amount of melting were sustained for a prolonged period of time. While the current basal temperature is about $-4.7^{\circ} \mathrm{C}$ (Thompson and others, 1988a; Fig. 3a), a decrease in the accumulation rate, an increase in ice thickness, or an increase in the mean annual surface temperature (currently $-7.3^{\circ} \mathrm{C}$ ) would tend to raise the basal temperature. Estimates of the changes in temperature and ice thickness necessary to raise the basal temperature to the pressure-melting point are obtained by numerically integrating the heat equation. A surface temperature $1{ }^{\circ} \mathrm{C}$ above the present value requires the ice to thicken by over $250 \mathrm{~m}$ to initiate basal melting. For a surface temperature rise of $4^{\circ} \mathrm{C}$, the ice must be only about $30 \mathrm{~m}$ thicker. However, no previously warmer period is evident in the isotopic record for the entire Holocene period. Additionally, the thicknesses required to initiate basal melting by a small surface warming are several times larger than would be possible, even with a doubling of the accumulation rate over an extended period of time. This suggests that conditions resulting in basal melting are unlikely.

\section{DISCUSSION}

The Late Glacial Stage record of climatic and environmental conditions on the Tibetan Plateau now begins to emerge (Fig. 9) from ice cores on the Dunde ice cap. The high alkalinity and $\mathrm{NaCl}$ concentrations reveal that the soluble dust deposited on the ice cap originates from the surrounding salt and calcareous deposits, with the Qaidam Basin probably contributing a significantly large portion of the soluble dust. The presence of similar cations and anions in both Holocene and LGS ice suggests that these sources have remained the same over the last $\sim 40000$ years. However, the reduced concentrations of dissolved species in LGS ice may reflect higher precipitation rates during the last glaciation. There is evidence (Chen and Bowler, 1985)

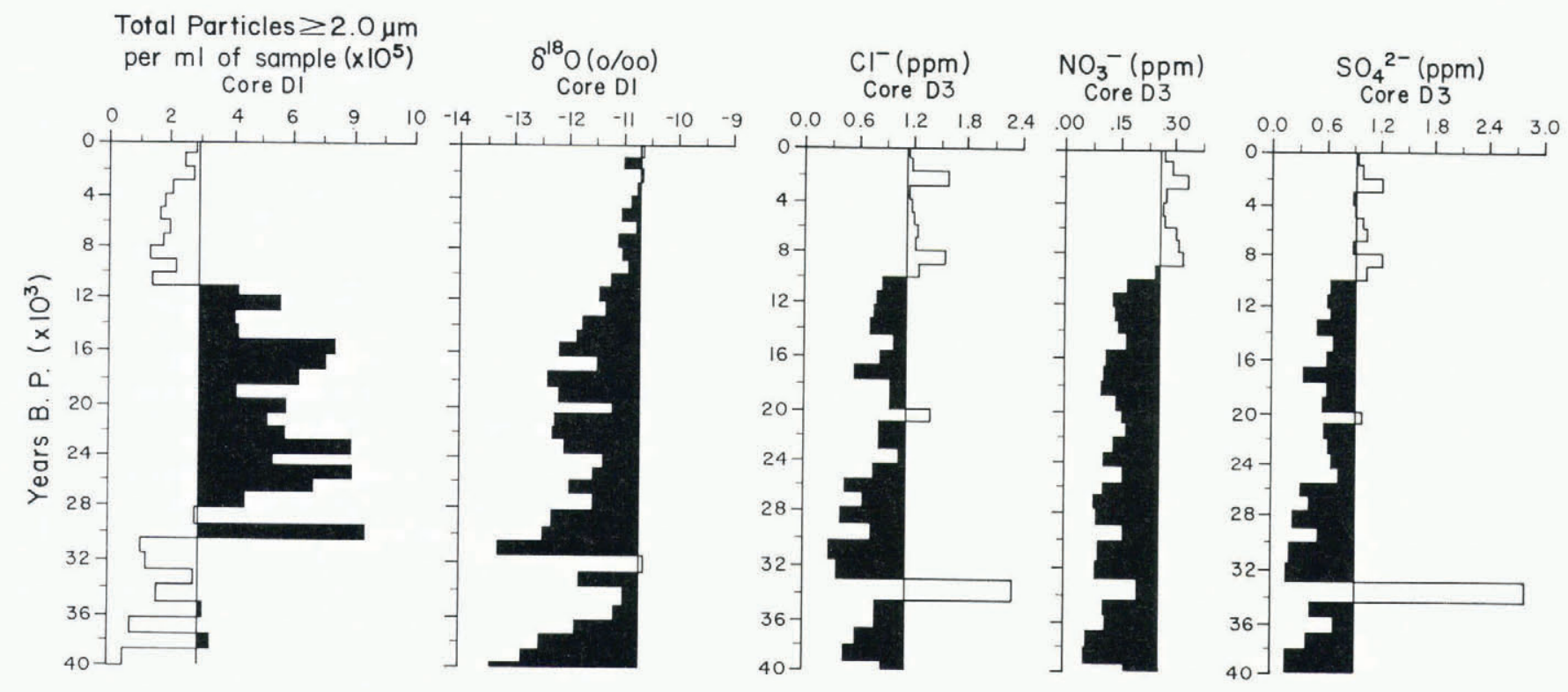

Fig. 9. The 1000 year averages of dust concentrations (diameters $\geqslant 2.0 \mu \mathrm{m}$ ), $\delta^{18} \mathrm{O}_{2} \mathrm{Cl}^{-}, \mathrm{NO}_{3}^{-}$and $\mathrm{SO}_{4}^{2-}$, are illustrated for the last 40000 years. The LGS-Holocene transition is characterized by an abrupt decrease in insoluble dust, an increase in dissolved species and a more gradual warming inferred from $\delta^{18} \mathrm{O}$. The average values represent all samples in the 40000 year record and not the individual 1000 year averages. There are $5 \mathrm{~m}$ of ice below the 40000 year model cut-off shown here (Thompson and others, 1989). 
suggesting that a large part of the Qaidam Basin was covered by fresh-water lakes during the LGS. Desiccation of the lakes began in the latter part of the LGS in response to reduced precipitation and/or precipitation/evaporation ratios, resulting in the formation of more extensive halite and calcareous deposits. As the Holocene is approached, the increasing ion concentrations and electrical conductivity probably reflects both decreased precipitation and increased dry surface area in the Qaidam Basin.

The enhanced dust deposition in LGS ice likely results from increased wind strength in response to increased baroclinicity (steeper isobars and isotherms) due to the expanded continental ice sheet in the northern hemisphere. The high winds from the deserts of western Asia deposited loess hundreds of feet thick across central and eastern China, extending to the Pacific Basin (Braaten and Cahill, 1986) and most likely to the North American continent. Under present-day conditions, large quantities of mineral dust are transported to the North Pacific each spring (Betzer and others, 1988). During the LGS, very large and discrete dust events blanketed the Dunde ice cap and most likely much of the extensively snow-covered and glacierized plateau, significantly altering the radiation balance. Growing evidence indicates that under the current climate regime albedo changes due to variation in Eurasian snow cover affects global climate. These include strong influences on the Asian summer monsoon system and the El Nino-Southern Oscillation phenomenon (Barnett and others, 1988). During the LGS the large short-term variations in albedo on the Tibetan Plateau due to large, multiple, discrete, high-altitude dust events may have increased the variability in the monsoonal system and, hence, of the global climate system. The decrease in dust deposition at the LGS/Holocene transition was rapid (within $\sim 40$ years) reflecting an abrupt and substantial change in the prevailing climatic conditions which severely limited the capability of the atmosphere to transport dust.

The $\delta^{18} \mathrm{O}$ record (Fig. 9) reveals an apparent warming between $\sim 38000$ and $\sim 30000$ year B.P. which is associated with less dust deposition. At about 30000 year B.P., full glacial conditions were re-established and dust deposition increased substantially and abruptly. Between 30000 to 10000 year B.P., concentrations of $\mathrm{Cl}^{-}$and $\mathrm{SO}_{4}^{2-}$ increased gradually as conditions became drier and the areal extent of salt and loess deposits increased. About 10750 year B.P. a marked increase in these species occured as drying of the fresh-water lakes was completed. Simultaneously, the insoluble dust decreased sharply (Figs $4 \mathrm{~b}$ and 9 ). The $8^{18} \mathrm{O}$ profile suggests a gradual warming while the aerosol (soluble and insoluble) data indicate rapid environmental changes including reduced wind intensity.

A most striking feature of the $\delta^{18} \mathrm{O}$ record (Fig. 4a) is the extreme warmth of the last 60 years with the warmest decades being the 1940s, 1950s, and 1980s. Using the $8^{18} \mathrm{O}$ record as a proxy of temperature, the last 60 years constitute one of the warmest periods in the entire record, equalling levels of the Holocene maximum 6000-8000 year B.P. (Fig. 4). Model results of Hansen and others (1988) suggest that the central part of the Asian continent may be one of the first places to exhibit an unambiguous signal of the anticipated "greenhouse warming". Certainly, the Dunde ice-core (D-1) results suggest that the recent warming on the Tibetan Plateau has been substantial. Recent radiosonde data from southern India (Flohn and Kapala, 1989) show that, in fact, the average tropospheric temperature has increased nearly $1^{\circ}$ since 1965.

\section{ACKNOWLEDGEMENTS}

This research was supported by the U.S. NSF Office of Climate Dynamics and the Division of Polar Programs (ATM-8519794), the National Geographic Society (3323-86), The Ohio State University, and Academia Sinica of China. We thank the many individuals who contributed to the success of this program, especially the 50 Chinese and American participants. Initial support was provided by the U.S. National Academy of Sciences' Committee for Scholarly Communication with the People's Republic of China. We thank the Fred C. Hansen Company for assistance in the modification of a tree-ring incremental measuring device for use in ice-core dating, S. Smith for illustrations and $\mathrm{K}$. Doddroe for typing. This paper is Contribution 711 of the Byrd Polar Research Center, The Ohio State University.

\section{REFERENCES}

Barnett, T.P., L. Dümenil, U. Schlese, and E. Roeckner. 1988. The effect of Eurasian snow cover on global climate. Science, 239(4839), 504-507.

Betzer, P.R., and 11 others. 1988. Long-range transport of giant mineral aerosol particles. Nature, 236(6199), 568-571.

Bolzan, J.F. 1985. Ice flow at the Dome C ice divide based on a deep temperature profile. J. Geophys. Res., 90(D5), 8111-8124.

Braaten, D.A. and T.A. Cahill. 1986. Size and composition of Asian dust transported to Hawaii. Atmos. Environ., 20(6), 1105-1109.

Chen, K. and J.M. Bowler. 1985. Late Pleistocene evolution of salt lakes in the Qaidam Basin, Qinghai Province, China. Palaeogeogr., Palaeoclimatol., Palaeoecol., 54, 87-104.

Crozaz, G., C.C. Langway, jr, and E. Picciotto. 1966. Artificial radioactivity reference horizons in Greenland firn. CRREL Res. Rep. 208.

Dansgaard, W., H.B. Clausen, N. Gundestrup, S.J. Johnsen, and C. Rygner. 1985. Dating and climatic interpretation of two deep Greenland ice cores. In C.C. Langway, jr, H. Oeschger, and W. Dansgaard, eds. Greenland ice core: geophysics, geochemistry, and the environment. Washington, DC, American Geophysical Union, 71-76. (Geophysical Monograph 33.)

De Angelis, M., N.I. Barkov, and V.N. Petrov. 1987. Aerosol concentrations over the last climatic cycle (160 kyr) from an Antarctic ice core. Nature, 325(6102), 318-321.

Domrös, M. and G. Peng. 1988. The climate of China. Berlin, Springer-Verlag.

Duval, P. and C. Lorius. 1980. Crystal size and climatic record down to the last ice age from Antarctic ice. Earth Planet. Sci. Lett., 48(1), 59-64.

Flohn, H. and H. Kapala. 1989. Changes of tropical sea-air interaction processes over a 30-year period. Nature, 338, 244-246.

Hammer, C.U., H.B. Clausen, W. Dansgaard, A. Neftel, R. Kristinsdottir, and E. Johnson. 1985. Continuous impurity analysis along the Dye 3 deep core. In C.C. Langway, jr, $\mathrm{H}$. Oeschger, and W. Dansgaard, eds. Greenland ice core: geophysics, geochemistry, and the environment. Washington, DC, American Geophysical Union, 90-94. (Geophysical Monograph 33.)

Hammer, C.U., H.B. Clausen, and H. Tauber. 1986. Ice-core dating of the Pleistocene/Holocene boundary applied to a calibration of the ${ }^{14} \mathrm{C}$ time scale. Radiocarbon, $28(2 \mathrm{~A})$, 284-291.

Hansen, J., and 7 others. 1988. Global climate changes as forecast by Goddard Institute for Space Studies threedimensional model. J. Geophys. Res., 93(D8), 9341-9364.

Herron, M.M. and C.C. Langway, jr. 1985. Chloride, nitrate, and sulfate in the Dye 3 and Camp Century, Greenland ice cores. In C.C. Langway, $j r, \mathrm{H}$. Oeschger, and W. Dansgaard, eds. Greenland ice core: geophysics, geochemistry, and the environment. Washington, DC, American Geophysical Union, 77-84. (Geophysical Monograph 33.)

Jezek, K.C. and L.G. Thompson. 1982. Interpretation of mono-pulse ice radar soundings on two Peruvian glaciers. IEEE Trans. Geosci. Remote Sensing, GE-20(3), 243-249.

Johnsen, S.J., W. Dansgaard, H.B. Clausen, and C.C. Langway, jr. 1972. Oxygen isotope profiles through the Antarctic and Greenland ice sheets. Nature, 235(5339), 429-434.

Koerner, R.M. 1977. Distribution of microparticles in a $299 \mathrm{~m}$ core through the Devon Island ice cap, Northwest Territories, Canada. International Association of Hydrological Sciences Publication 118 (Symposium at Grenoble 1975 - Isotopes and Impurities in Snow and Ice), 371-376.

Koerner, R.M. and D.A. Fisher. 1979. Discontinuous flow, ice texture, and dirt content in the basal layers of 
the Devon Island ice cap. J. Glaciol., 23(89), 209-222.

Koerner, R.M., D.A. Fisher, and W.S.B. Paterson. 1987. Wisconsinan and pre-Wisconsinan ice thicknesses on Ellesmere Island, Canada: inferences from ice cores. Can. J. Earth Sci., 24(2), 296-301.

Legrand, M.R. and R.J. Delmas. 1988. Soluble impurities in four Antarctic ice cores over the last 30000 years. Ann. Glaciol., 10, 116-120.

Paterson, W.S.B., and 7 others. 1977. An oxygen-isotope climatic record from the Devon Island ice cap, Arctic Canada. Nature, 266(5602), 508-511.

Petit, J.R., P. Duval, and C. Lorius. 1987. Long-term climatic changes indicated by crystal growth in polar ice. Nature, 326(6108), 62-64.

Picciotto, E. and S. Wilgain. 1963. Fission products in Antarctic snow; a reference level for measuring accumulation. J. Geophys. Res., 68(21), 5965-5972.

Raymond, C.F. 1983. Deformation in the vicinity of ice divides. J. Glaciol., 29(103), 357-373.

Reeh, N. 1988. A flow-line model for calculating the surface profile and the velocity, strain-rate, and stress fields in an ice sheet. J. Glaciol., 34(116), 46-54.

Thompson, L.G. 1977. Microparticles, ice sheets and climate. Ohio State University. Institute of Polar Studies. Report 64.

Thompson, L.G. In press. Interpretation of short-pulse radar soundings from low latitude, high altitude glaciers of Peru and China. Geol. Surv. Can., 1989.

Thompson, L.G. and E. Mosley-Thompson. 1981a. Microparticle concentration variations linked with climatic change: evidence from polar ice cores. Science, 212(4496), 812-815.

Thompson, L.G., E. Mosley-Thompson, and J.R. Petit. 1981b. Glaciological interpretation of microparticle concentrations from the French 905-m Dome C, Antarctica core. International Association of Hydrological Sciences Publication 131 (Symposium at Canberra 1979 - Sea Level, Ice and Climatic Change), 227-234.

Thompson, L.G., Wu Xiaoling, E. Mosley-Thompson, and Xie Zichu. 1988a. Climatic records from the Dunde Ice Cap, China. Ann. Glaciol., 10, 178-182.

Thompson, L.G., E. Mosley-Thompson, Wu Xiaoling, and Xie Zichu. 1988b. Wisconsin/Würm glacial stage ice in the subtropical Dunde Ice Cap, China. GeoJournal, 17(4), 517-523.

Thompson, L.G., and 9 others. 1989. Holocene-Late Pleistocene climatic ice core records from Qinghai-Tibetan Plateau. Science, 246(4929), 474-477.

Wagenbach, D. 1989. Environmental records in alpine glaciers. In Oeschger, H. and C.C. Langway, jr, eds., The environmental record in glaciers and ice sheets. Chichester, etc., John Wiley and Sons, 69-83. 